\title{
ADAPTATION OF NON-SUNDANESE REPORTERS IN COLLECTING NEWS IN BANDUNG CITY
}

\author{
Maila Siti Nurmala \\ UIN Sunan Gunung Djati Bandung, Indonesia \\ manjar315@gmail.com \\ Darajat Wibawa \\ UIN Sunan Gunung Djati Bandung, Indonesia \\ khoiruddin@uinsgd.ac.id \\ Khoiruddin Muchtar \\ UIN Sunan Gunung Djati Bandung, Indonesia \\ darajat.wibawa@uinsgd.ac.id
}

\begin{abstract}
The adaptation of non-Sundanese reporters is the object of this study; the aim is to find out the views of non-Sundanese journalists on Sundanese society in the city of Bandung, the self-concept owned by non-Sundanese journalists and how the adaptation of non-Sundanese journalists in gathering news. The methodology used is phenomenology with symbolic interaction theory. This study uses a qualitative approach: observation techniques, in-depth interviews do the process of data collection. The results showed that Non-Sundanese Journalists in Bandung City, most of the opinion. Sundanese people have a positive nature and easy to accept other people from outside the region who have cultural differences. For non-Sundanese journalists, when carrying out their profession as a journalist, they should have advantages compared to indigenous journalists so that they can survive in carrying out their duties in gathering news. Having education that is directed and professional in their fields, is capital in carrying out their profession so that they will become journalists who are expected and needed by others, wherever they are. NonSundanese journalists are expected to be able to adapt or adjust to the perceived differences in gathering news, especially from cultural and linguistic differences, so that enormous courage and patience are needed.
\end{abstract}

Keywords: Adaptation; Non-Sundanese Journalist; Gathering News; Bandung. 


\begin{abstract}
Abstrak
Adaptasi wartawan non Sunda menjadi objek dalam penelitian ini, tujuannya untuk mengetahui pandangan wartawan non Sunda terhadap masyarkat sunda di Kota Bandung, konsep diri yang dimiliki wartawan non Sunda dan bagaimana adaptasi wartawan non Sunda dalam menghimpun berita. Metodologi yang digunakan adalah fenomenologi dengan teori Interaksi Simbolik. Penelitian ini menggunakan pendekatan kualitatif, proses pengumpulan data dilakukan dengan teknik observasi, wawancara mendalam. Hasil penelitian menunjukan bahwa, Wartawan Non Sunda di Kota Bandung, sebagian besar berpendapat masyarakat Sunda memiliki sifat yang positif dan mudah untuk menerim orang lain dari luar daerah yang memiliki perbedaan budaya. Bagi wartawan non sunda, ketika menjalankan profesinya sebagai wartawan, hendaknya memiliki kelebihan dibanding dengan wartawan pribumi, sehingga mampu bertahan menjalani tugasnya dalam menghimpun berita. Memiliki pendidikan yang terarah dan professional pada bidangnya, merupakan modal dalam menjalankan profesinya, sehingga akan menjadi wartawan yang diharapkan dan dibutuhkan orang lain, dimanapun berada. Wartawan non sunda diharapakan dapat melakukan adaptasi atau penyesuaian terhadap perbedaan yang dirasakan dalam menghimpun berita, terutama dari perbedaan budaya dan Bahasa, sehingga diperlukan keberanian dan kesabaran yang lebih besar.
\end{abstract}

Kata Kunci: Adaptasi; Wartawan Non Sunda; Menghimpun Berita; Bandung.

Accepted : April 21, 2020 Reviewed: May 6, 2020 Published: June 1, 2020

\title{
Introduction
}

To build a harmonious relationship with the new environment, nonSundanese journalists are required to have communication skills. Communication is carried out to understand habits, accept habits, and be accepted as nomads. Non-Sundanese journalists who have successfully adapted to the city of Bandung, their work as journalists to gather news, do not find many obstacles. When non-Sundanese journalists communicate with Sundanese people, it can be called intercultural communication. Larry S Samovar defines intercultural dialogue as a form of communication that involves interactions between people whose cultural perceptions and symbol systems are quite different. (Darmastuti, 2013).

Communication that involves non-Sundanese journalists with Sundanese people is called intercultural communication. According to 
Muchtar, et al. (2016) intercultural communication includes communication that involves participants who represent individuals, between individuals, groups with the pressure of different cultural backgrounds that affect the communication behavior of the participants. In this research, communication is defined as a way for non-Sundanese journalists to adapt to Bandung to obtain information or dig up the news in their coverage.

Journalists who work in the city of Bandung are required to learn Sundanese grammar, especially regarding karma, because etiquette or more commonly called manners, will provide and show the right way to act.

So this study wants to find out specifically about Non-Sundanese journalists in gathering news in the city of Bandung, in which interaction is the main factor in getting data in journalistic activities, even though the reporting process is not as easy as imagined because Adaptation is needed.

Several similar studies have been carried out before, such as the Work Practices and the Adaptation Process of Daily Newspaper Journalists in the Era of Media Convergence (Rivki, 2010). Mining nomadic Parental Communication Socialization in Forming the MiningKabau Cultural Ethnic Identity to Children (Yulita, 2015), and the Experience of Women's News in the Campus Press (Karina, 2015). The research that will be carried out focuses more on the workings of nonSundanese journalists in gathering news in journalistic activities.

This research was conducted in the city of Bandung, in several places following the informant's agreement. There are several essential considerations why this research was conducted in the city of Bandung, including because of the availability of the necessary data, access to mobility, and supporting funds in this study.

For this research to be more focused, the research questions were derived from several aspects of Adaptation as follows: How do nonSundanese journalists view Sundanese society in Bandung? What is the self-concept that non-Sundanese reporters have when collecting news in Bandung? Journalistic activities in the city of Bandung.

This study uses the phenomenological method from Edmund Husserl. The essence of the real phenomenon is behind what appears. 
According to the tradition of phenomenology, the first look (first look) has not been able to make the aspect reveal the nature of himself. Therefore, a second look (second look) is needed, which is called intuitive observation. Intuitive observation must go through three stages of reduction or three stages of filtering. Namely phenomenological reduction, eidetic reduction, and transcendental reduction. Through these three stages, Husserl hopes that he will be able to make this phenomenon reveal the essence of himself as pure as possible (Rapar, 1996).

The phenomenological method is beneficial for scientific research. Phenomenology methods need to be used together with other methods. As a research method, phenomenology is often known as a qualitative descriptive method with a constructivist paradigm. In epistemology, there is an interaction between the researcher and the subject under study. Meanwhile, from the ecological perspective, researchers conduct values, ethics, and moral choices as an integral part of the research. Researchers are facilitators who bridge the diversity of subjectivity of social actors to reconstruct social reality

\section{Research Method}

This research was conducted in the city of Bandung, in several places according to perpetual information. There are several essential considerations why this research was conducted in the city of Bandung, including because of the availability of the necessary data, access to mobility, and funds that are enduring in this study.

For this research to be more focused, the research questions were derived from several aspects of Adaptation as follows: How do nonSundanese journalists view Sundanese society in Bandung? What is the self-concept that non-Sundanese reporters have when collecting news in Bandung? Journalistic activities in the city of Bandung. This study uses the phenomenological method from Edmund Husserl.

The essence of the real phenomenon is behind what appears. According to the tradition of phenomenology, the first look (first look) has not been able to make the event reveal the nature of himself. Therefore, a second look (second look) is needed, which is called intuitive observation. Intuitive observation must go through three stages of 
reduction or three stages of filtering. Namely phenomenological reduction, eidetic reduction, and transcendental reduction. Through these three stages, Husserl hopes that he will be able to make this phenomenon reveal the essence of himself as pure as possible (Rapar, 1996).

The phenomenological method is beneficial for scientific research. Phenomenology methods need to be used together with other methods. As a research method, phenomenology is often known as a qualitative descriptive method with a constructivist paradigm. In epistemology, there is an interaction between the researcher and the subject under study. Meanwhile, from the ecological perspective, researchers conduct values, ethics, and moral choices as an integral part of the research. Researchers are facilitators who bridge the diversity of the subjectivity of social actors to reconstruct social reality.

\section{Results and Discussion}

Has been discussed at the sub-step of the study, that this study uses a qualitative approach. The qualitative approach is felt to be in line with this research to understand phenomena about what is experienced by research subjects such as behavior, perception, motivation, action, etc. holistically, and with descriptions in the form of words and language, in a unique natural context and used a variety of natural methods (Moleong, 2006)

In his research studies, this research uses phenomenology. The choice of phenomenology aims to find out the world from the perspective of the person who experiences it directly or is related to the natural characteristics of human experience and the meaning it attaches. Following the theory of Phenomenology put forward by Alfred Schutz, the social world is an interpretive reality (Kuswarno, 2009). Human action and all events that have occurred are considered as a meaningful reality, in the sense that individuals can give meaning to that reality.

The results of the research that have been presented regarding the views, self-concept, and adaptation of Non-Sundanese journalists in Bandung in collecting news, will then be analyzed using several appropriate references. The following analysis of research on the three aspects, including: 
Non-Sundanese Journalists' views of the Sundanese community in the city of Bandung

Analysis of the opinions of non-Sundanese journalists on the Sundanese community in Bandung resulted in how non-Sundanese journalists view the situation of Sundanese people in Bandung, both attitude, habits, and language. The views of non-Sundanese journalists towards Sundanese people are based on information that is processed by the minds of each informant who acts as a non-Sundanese reporter.

The intention is defined as the process of a person's conversation with himself, not found in the individual. The distinctive characteristic of the mind is the ability of the individual to bring up in himself not only one response but also the response of the community as a whole. That is what is called the mind (Herbert Mead in Nurhadi (2015).

Mead's explanation of the mind as experienced by non-Sundanese journalists in providing their views on the Sundanese people who incidentally as a resource. The picture given by non-Sundanese journalists originated from his response to the Sundanese community so that what came to be called an assessment was supported by information related to the Sundanese people from outside.

Based on the findings in the field about the views of non-Sundanese reporters towards the Sundanese community in the city of Bandung, the researchers focused on two things: the response of non-Sundanese reporters and the evaluation of non-Sundanese reporters towards Sundanese people in Bandung. Responses and judgments are social phenomena that grow and develop in social processes as a result of the interaction. The mind is formed after self-conversation (self-conversation) (Mead in Mufid, 2010).

Based on the results of research in the field related to the response of Non-Sundanese journalists to the Sundanese community in the city of Bandung, it explains how non-Sundanese journalists believe in themselves about the attitudes and habits of the Sundanese people who were their sources. Most of the informants think that Sundanese people have a positive nature and are easy to accept as someone from outside the region who has cultural differences. The response that non-Sundanese 
reporters have towards Sundanese people they have not yet met comes from information in the environment related to the nature of Sundanese society that spreads from one ear to another until it becomes a social phenomenon that develops into a social process due to discussions from one party to another until growing knowledge of non-Sundanese journalists towards the Sundanese they believe.

Symbolic interactionism can be defined as a way of interpreting and giving meaning to the environment around us through interacting with others. The symbolic perspective of interactionism bases its view on the assumption that humans develop a complex set of symbols to give meaning to the world. Because sense arises through human interaction with the environment (Mufid, 2010).

The results of the study explained that the evaluation of nonSundanese reporters towards Sundanese people before and after becoming journalists was the same. The form of the review carried out by non-Sundanese journalists is the process of giving meaning, as explained by Mufid above related to symbolic interactions. The results of the assessment can be concluded when non-Sundanese journalists interact with Sundanese people in the city of Bandung

in gathering news. Non-Sundanese journalists can judge the Bandung community to be friendly when interacting directly with the Bandung community as its guest speaker.

Based on the findings in the field, one of the informants, Aman Hasibuan, said that his evaluation of the Bandung community was either the same before or before because, according to him, the attitude of the Bandung community was good or bad how to carry themselves. When becoming a newcomer, it should follow and understand the habits of the native population so that they can be readily accepted, because as a newcomer or migrant means being a minority voice in the group.

The symbolic interaction perspective seeks to understand human behavior from the subject's perspective. This perspective suggests that human behavior must be seen as a process that allows humans to shape and regulate their conduct by considering the expectations of others who become their interaction partners (Mulyana, 2006).

One of the goals of communication is to understand people as communicators must know the genuine aspirations of people about what 
they want and not communicate with their own volition. When nonSundanese journalists interact and communicate with their sources, Sundanese can understand one another, especially non-Sundanese journalists, as comers by delivering to understand the Sundanese character (Cangara, 2002).

\section{The Self-Concept of Non-Sundanese Journalists in Collecting News}

The self-concept of non-Sundanese reporters in gathering news explains how non-Sundanese reporters assess their abilities and strengths related to the process of covering news in the city of Bandung. The method of determining one's knowledge with experience and intensity of interaction with others so that the informant has a picture of the desires that should be taken on himself.

Basically self is the ability to accept oneself as a subject or object. Self is where people give responses to what he shows to others to answer to himself, but also respond to himself, talk and answer himself as others answer to him, so that it has a behavior where the individual becomes an object for himself (Mead in Nurhadi, 2015).

Based on findings in the field related to the advantages possessed by non-Sundanese journalists compared to journalists from Bandung produced two groups, namely, the same and have differences. However, both groups claimed that in carrying out their profession as journalists, they have their advantages so that they can survive in carrying out their duties in gathering news, moreover becoming a journalist is the choice and desire of each informant.

As Romli said, there are at least six standards of the right journalist profession (real journalist), one of which is well motivated and hight idealism, meaning that they have proper motivation and high aspiration when they enter the world of journalism (Romli, 2009).

In the analysis related to Romli's explanation, all the informants explained that both of the confessions had the same or different advantages from the Sundanese reporters in the city of Bandung claiming to have a goal as a journalist to be able to carry out their duties in covering the news. The aim of non-Sundanese journalists is the 
motivation Romli explained related to the right professional journalist standards.

From the results of the interviews, groups that claimed to have advantages compared to journalists generally stated that they had an education that was directed in their fields so that even though carrying out their profession in other people's areas with cultural differences and everything else was not a problem because of having education. Professional standards for journalists are Well educated, which means well educated. Journalists should go through the stages of journalism education, at least through journalism training that is well organized and well-directed (Romli, 2003).

Journalists are professionals, like doctors or lawyers who have their expertise and do not have other professions (hunting, processing, and writing news) (Romli, 2003).

Based on the findings in the field, the informant explained that one of the hopes of being able to gather news is to be creative and inferior. Being a journalist, especially in a city, people need more creativity than Bandung journalists in general, because in carrying out their profession, non-Sundanese journalists are expected to get more difficulties from the many differences to be demanded to be creative. Creative attitude is considered very influenced by low self-esteemournalists. Therefore informants hope as non-Sundanese reporters can be inferior to be creative.

One of the conditions that must be met to become a journalist is being able to eliminate feelings of inferiority. Feelings of inadequacy can hinder journalists from getting optimal news material. Self-esteem becomes a mental obstacle for journalists to be more creative and critical in digging information (Yunus, 2010).

Also, one informant said he hoped to speak Sundanese to make it easier to carry out his profession in Bandung. The statement refers to Yunus' opinion in his book "Applied Journalism" that one of the competencies that journalists must have in addition to writing, journalists should have the ability to speak. If in the case of non-Sundanese reporters in Bandung, the ability to talk in Sundanese language. 


\section{Adaptation of Non-Sundanese Journalists in Journalistic Activities}

At the most general level, it uses the term society, which means a continuous social process that precedes the mind and self. According to personal understanding, society influences, gives ability through selfcriticism, to control oneself (Mead in Nurhadi, 2015).

As the results of the adaptation of non-Sundanese journalists explain how non-Sundanese journalists can survive. How to adapt through criticism given by the surrounding community for a long time and continues until they can control themselves from differences.

Adaptation is a process of adjustment of individuals, groups, and social units to norms, processes of change, or a condition created. More about the adjustment process. Likewise, the non-Sundanese journalists who work in Bandung make adjustments to the differences they felt while in Bandung in collecting good news from cultural and language differences (Soekanto, 2000).

Based on the results in the field, the researcher focused on two things related to the adaptation of non-Sundanese journalists in journalistic activities, namely, the mentality of the first time coverage in Bandung and the obstacles encountered.

Being a reporter, one must be prepared mentally and physically. Likewise, what is explained from the findings in the field is that as a nonSundanese journalist, he should have a strong mentality with the many differences he faces. As the experience of the eight informants related to the first coverage process in Bandung, of course, it has several obstacles such as differences in the character of the people used as resource persons, language differences, and differences inhabit so that a long adaptation process is needed, but in the process of reporting for the first time in Bandung It is estimated that non-Sundanese journalists have not had time to carry out the adaptation process so that more courage is needed (Romli, 2003)

Based on the results of interviews with the eight informants, one of them said that there was no difference in the first time of reporting, but the personality and the way to bring yourself well into the scope of Sundanese society so that they were able to easily cover the news despite meeting and entering the culture and new circumstances. 
Self-identity within the range of developmental psychology refers to two central notions, one of which is that self-identity is used to explain the combination of personality characteristics and social style that one uses to reveal himself and how others recognize him (Grotevant in Nurhadi, 2015).

The way of carrying oneself carried out by non-Sundanese journalists in the city of Bandung when it was first covered was one of the ongoing adaptations that became a way of channeling social tensions that had the effect of further providing the permanence between non-Sundanese journalists and Sundanese people. One of the goals of adaptation is to overcome obstacles from the environment (Aminuddin, 2000)

In the process of gathering news, what journalists should highlight is the way of communication, to produce maximum data to provide relevant news. Still, based on findings in the field, non-Sundanese journalists claim to have obstacles in gathering intelligence due to the lack of understood Sundanese language. While the tongue is a tool used in communication.

Word is functionally defined as a shared tool for expressing ideas. Language is emphasized to be divided because language can only be understood if there is agreement among members of social groups to use it (Mercy, 1994). Professional journalist competencies that must be possessed in the global era like now, one of which is speaking competence (Yancheff in Yunus, 2010)

It is estimated that by understanding the local language of nonSundanese reporters can communicate well so that as migrants can be well received and do not get significant obstacles related to gathering news as non-Sundanese reporters in the city of Bandung. This is by the function of communication as a social function; communication is essential to build our self-concept, self-actualization, for survival, to obtain happiness, to avoid pressure and tension, among others through entertaining conversation, and to foster relationships with others (Mulyana 2001)

Non-Sundanese journalists need to learn Sundanese language to get around the obstacles they face. When non-Sundanese reporters can work around these obstacles to undergo their profession as a reporter gathering, the news will run smoothly like journalists in general. 
The results of research using phenomenological studies, this study never tried to seek opinions from informants, whether this is true or false. However, in phenomenological analysis, researchers try to "reduce" the awareness of informants in understanding the phenomenon. From the results of the study, the eight informants gave insight, meaning, or experience regarding the adaptation of non-Sundanese reporters in gathering news in Bandung from the perspective of their profession as journalists.

\section{Conclusion}

Non-Sundanese reporters in the city of Bandung, most of the opinion Sundanese people have a positive nature and easy to accept other people from outside the region who have cultural differences. The attitude of the people of West Java towards non-Sundanese journalists will depend on how non-Sundanese journalists build mutual understanding and trust. When becoming a newcomer, it should follow and understand the habits of the native population so that they can be readily accepted, because as a newcomer or migrant means being a minority voice in the group.

For non-Sundanese journalists, when carrying out their profession as a journalist, they should have advantages compared to indigenous journalists so that they can survive in carrying out their duties in gathering news, especially being a journalist is a profession choice that must be pursued. Having a directed and professional education in their field is capital in carrying out their profession so that they will become reporters who are expected and needed by others.

Being a journalist, especially in the city of Bandung, requires more creativity, compared to Bandung journalists in general, because in carrying out his profession, non-Sundanese journalists are expected to have more difficulty from the many differences to be demanded to be creative. Able to eliminate feelings of inferiority, because feelings of inadequacy can hinder journalists from getting optimal news material, self-esteem becomes a mental obstacle for journalists to be more creative and critical in information gathering.

Non-Sundanese journalists are expected to be able to make adjustments to the perceived differences while in the city of Bandung in 
gathering good news from differences in culture and language. Related to the first coverage process in the city of Bandung certainly has several obstacles, such as differences in the character of the people used as resource persons, differences in language, and differences inhabit so that it takes a long adaptation process so that it requires enormous courage and patience.

When the process of collecting news, non-Sundanese journalists have obstacles in gathering intelligence, due to the lack of understood Sundanese language. While the word is a tool used in communication. Sundanese language learning becomes essential for non-Sundanese reporters, so they can communicate well so that as migrants can be well received and do not get significant obstacles related to collecting news as non-Sundanese reporters in the city of Bandung.

\section{Bibliography}

Darmastuti,

$\mathrm{R}$.

(2013). Mindfulness

dalam

Komunikasi Antarbudaya.Yogyakarta: Buku Litera.

Karina, R. (2015). Pengalaman Pewarta Perempuan di Pers Kampus. Bandung: Skripsi Unisba.

Kuswarno, E. (2009). Fenomenologi. Bandung: Widya Padjajaran.

Muchtar, K., Koswara, I., \& Setiaman, A. (2016). Komunikasi Antar Budaya dalam Persefektif Antropologi. Jurnal Manajemen Komunikasi, 1(1), 113-124.

Mufid, M. (2010). Etika dan Filsafat Komunikasi. Jakarta: Kencana.

Mulyana, D. (2004). Ilmu Komunikasi Suatu Pengantar. Bandung: Remaja Rosdakarya. Rosdakarya. (2008). Ilmu Komunikasi Suatu Pengantar. Bandung: Remaja

Nurhadi, Z. F. (2015). Teori-teori Komunikasi. Bogor: Ghalia Indonesia.

Rapar, J. H. (1996). Pengantar Filsafat. Yogyakarta: Kanisius.

Rivki. (2010). Perkembangan Praktik Kerja dan Proses Adaptasi Wartawan Surat Kabar Harian dalam Era Konvergensi Media. Bandung: Skripsi Unpad.

Romli, A.S.M. (2003). Jurnalistik terapan. Bandung: Simbiosa Rekatama Media. (2008). Kamus Jurnalistik. Bandung: Simbiosa Rekatama Media. 
(2009). Jurnalistik Praktis Untuk Pemula. Bandung: Remaja Rosdakarya.

Soekanto, S. (2000). Sosiologi: Suatu Pengantar. Jakarta: Rajawali Pers.

Yulita, D. T. (2015). Sosialisasi Komunikasi Orang Tua Perantau Minang dalam Membentuk Identitas Etnik Kebudayaan Minangkabau terhadap Anak. Bandung: Skripsi Unisba.

Yunus, S. (2010). Jurnalistik Terapan. Bogor: Ghalia Indonesia. 